\title{
Nitrogen balance in adult female mink (Mustela vison) in response to normal feeding and short-term fasting
}

\author{
BY ANNE-HELENE TAUSON ${ }^{1}$, JAN ELNIF $^{1}$ AND SØREN WAMBERG ${ }^{2 *}$ \\ ${ }^{1}$ Division of Nutrition and Production, Department of Animal Science and Animal Health, \\ The Royal Veterinary and Agricultural University, DK-1870 Frederiksberg C, Denmark \\ ${ }^{2}$ Department of Physiology, Institute of Medical Biology, Odense University, \\ DK-5000 Odense C, Denmark
}

(Received 4 June 1996 - Revised 29 October 1996 - Accepted 14 November 1996)

\begin{abstract}
Ten adult female mink (Mustela vison) were studied in a $7 \mathrm{~d}$ balance experiment consisting of a $2 \mathrm{~d}$ pre-surgery feeding period, followed by surgery, $1 \mathrm{~d}$ of recovery, $4 \mathrm{~d}$ of ad libitum feeding, and a $2 \mathrm{~d}$ fasting period. In this experiment (Expt $A$ ) the animals had osmotic pumps implanted for continuous release of radioactively-labelled $p$-aminohippuric acid ( $p$-aminobenzoyl-2- $\left[{ }^{3} \mathrm{H}\right] \mathrm{glycine} ;\left[{ }^{3} \mathrm{H}\right] \mathrm{PAH} ; n$ 10) and ${ }^{14} \mathrm{C}$-labelled inulin $\left(\left[{ }^{14} \mathrm{C}\right] \mathrm{IN} ; \boldsymbol{n}\right.$ 5). Repeated $24 \mathrm{~h}$ collections of urine, corrected to $100 \%$ $\left[{ }^{3} \mathrm{H}\right] \mathrm{PAH}$ or $\left[{ }^{14} \mathrm{C}\right] \mathrm{IN}$ recovery, were used for accurate determination of $\mathrm{N}$ balances, $24 \mathrm{~h}$ urinary excretion of urea, creatinine, and total $\mathrm{N}$, and calculation of mean $24 \mathrm{~h}$ renal clearance rates for endogenous creatinine and inulin. $\mathrm{N}$ balances were slightly below zero, but not significantly different between feeding and fasting periods, indicating that correction to $100 \%\left[{ }^{3} \mathrm{H}\right] \mathrm{PAH}$ recovery resulted in slight overestimation of the final balances. During fasting, withdrawal of the dietary water and protein loads resulted in a dramatic decline in $24 \mathrm{~h}$ urinary volume, and urea and creatinine excretion. Large individual variations in $24 \mathrm{~h}$ urinary creatinine excretion (with relative variation coefficients up to $30 \%$ ) confirmed that this is an unreliable index of the completeness of urine collection. In this respect, recovery rates of $\left[{ }^{3} \mathbf{H}\right] \mathrm{PAH}$ proved far more consistent. Renal clearance values obtained in fed mink were in fair agreement with published data from cats, dogs and ferrets (Mustela putorius furo). Inulin clearance was about $30 \%$ higher than endogenous creatinine clearance, although its decline in response to fasting was not significant. In a separate study (Expt B) another ten female mink were equipped with osmotic pumps containing $\left[{ }^{3} \mathrm{H}\right] \mathrm{PAH}$ for determination of $24 \mathrm{~h}$ excretion rates of purine derivatives. During feeding, allantoin accounted for more than $97 \%$ of the excretion of purine derivatives in urine, uric acid making up less than $2.5 \%$, xanthine and hypoxanthine less than $1 \%$. In fasted animals, urinary excretion of each of these purine derivatives declined to less than $50 \%$ of the feeding value. In conclusion, an experimental technique is presented for efficient and accurate measurements of daily urinary excretion of nitrogenous constituents, which allows for correct determination of $\mathrm{N}$ balances in adult mink and, presumably, in other mammalian species.
\end{abstract}

Carnivores: $p$-Amino $\left[{ }^{3} \mathrm{H}\right]$ hippuric acid: ${ }^{14} \mathrm{C}$-labelled inulin: $\mathrm{N}$ balance: Osmotic pumps

In studies of human and animal nutrition, the balance technique is generally accepted as a useful method for assessing nutritional requirements under well-defined physiological conditions (Fomon \& Owen, 1962; Baker, 1986). In the case of N, however, this technique has often led to overestimation of the $\mathrm{N}$ balance, mainly due to inaccuracies in quantitative urine collection and, to a lesser extent, to loss of volatile nitrogenous compounds (van Es, 1975; Oddoye \& Margen, 1979; Neergaard, 1981; Just et al. 1982; Eggum, 1989). 
In carnivores, such as mink (Mustela vison), cats and ferrets (Mustela putorius furo), this problem is of paramount importance because, owing to the high concentration of nitrogenous substances in the urine, incomplete urine collection will result in considerable experimental errors. Furthermore, these carnivores have the habit of squirting urine and urinating on top of the faeces, which may further limit the accuracy of excreta collection and, hence, balance calculations. Therefore, data derived from $\mathrm{N}$ balance studies with carnivores confined in conventional metabolic cages often result in $\mathrm{N}$ balances which are substantially higher than justified for the physiological state of the animals studied (mink: Skrede, 1978; Charlet-Lery et al. 1980; Glem-Hansen, 1980; Berg et al. 1984; ferret: Jarosz \& Barabasz, 1988; cat: Miller \& Allison, 1958). Taken together with the shortcomings of other experimental methods, this has made determination of the protein requirement of carnivores extremely difficult, and only few reliable data exist, derived mainly from production experiments, for the various life processes (growing cats: Fox et al. 1973; growing mink: Skrede, 1978; Työppönen et al. 1986, 1987; Børsting \& Clausen, 1996; pregnant and lactating cats: Piechota et al. 1995; lactating mink: Glem-Hansen, 1979).

In an attempt to quantify the percentage losses of urinary $\mathrm{N}$ in balance studies with mink when conventional collection and washing procedures were applied, Elnif (1992) estimated that about $65 \%$ of the total urinary $N$ was retrieved. The losses were mainly due to incompleteness of collection of excreta, while only a minor amount was lost as volatile $\mathrm{N}$, measured in a respiration unit. $\mathrm{N}$ retrieval can be further improved by a refined collection and washing technique (A.-H. Tauson, unpublished results). Combining this procedure and the use of osmotic pumps for continuous release and subsequent control of the excretion of labelled urinary markers, Wamberg et al. $(1996 a, b)$ found that on average $78 \%$ of the daily excretion of urinary $\mathrm{N}$ could be accounted for in the urine collected.

The objectives of the present study were to make use of osmotic pumps, containing radioactively-labelled $p$-aminohippuric acid ( $p$-aminobenzoyl-2- $\left[{ }^{3} \mathrm{H}\right]$ glycine; $\left.\left[{ }^{3} \mathrm{H}\right] \mathrm{PAH}\right)$ and ${ }^{14} \mathrm{C}$-labelled inulin $\left(\left[{ }^{14} \mathrm{C}\right] \mathrm{IN}\right)$, for accurate determination of quantitative $\mathrm{N}$ balances in fed and fasted adult female mink, and to evaluate the effects of feeding and fasting on urinary excretion rates of some $\mathrm{N}$ metabolites, including purine derivatives. In addition, preliminary values for mean $24 \mathrm{~h}$ renal clearances of inulin (INC) and endogenous creatinine (ENCC) are presented.

\section{MATERIALS AND METHODS}

\section{Animals}

Expt A. Ten 2-year-old non-pregnant female mink of the pastel colour type, weighing approximately $1100 \mathrm{~g}$ were used for measurements of $\mathrm{N}$ balances, urinary excretion of $\mathrm{N}$ metabolites and changes in nitrogenous plasma constituents during normal feeding and short-term fasting. The females were equipped with implanted osmotic pumps containing $\left[{ }^{3} \mathrm{H}\right] \mathrm{PAH}(n 10)$ and $\left[{ }^{14} \mathrm{C}\right] \mathrm{IN}(n)$; see pp. 85-86).

Expt $B$. In a separate experiment, blood and urine were collected from another ten adult female pastel mink with implanted osmotic pumps containing $\left[{ }^{3} \mathrm{H}\right] \mathrm{PAH}$, for the determination of changes in plasma constituents and in $24 \mathrm{~h}$ urinary excretion of purine derivatives in response to feeding and fasting. 


\section{Housing and feeding}

The animals were plasmacytosis-free and appeared healthy when transferred to the laboratory (temperature $14-16^{\circ}$, relative humidity $30-50 \%$, and a $10 \mathrm{~h}$ light-14h dark cycle) and were confined in individual metabolism cages for a conditioning period of 1 week before the start of the experiment. Once daily they were fed on a conventional wet mink diet with a DM content of $312 \mathrm{~g} / \mathrm{kg}$ and a crude protein $(\mathrm{N} \times 6.25$; $\mathrm{CP})$ content of $177 \mathrm{~g} / \mathrm{kg}$ (Wamberg et al. 1996d), and given free access to drinking water throughout the study. The experimental procedure, including feeding, housing and treatment of the animals, blood sampling, and details of the in vitro and in vivo function of the osmotic pumps, has been described in detail elsewhere (Wamberg et al. 1996a,d).

\section{Balance studies}

All animals were studied for two consecutive $24 \mathrm{~h}$ pre-experimental collection periods (days -2 and -1 ; see Fig. 1) after which (day 0) they had a 2 ml osmotic pump (Alzet ${ }^{\circledR}$, model 2ML1; Alzo Corp., Palo Alto, CA, USA) implanted intraperitoneally during shortterm ketamine anaesthesia (Wamberg et al. 1996c). During the next $24 \mathrm{~h}$ the animals were allowed to recover from surgery and, consequently, all collected material was discarded. Another four consecutive $24 \mathrm{~h}$ collection periods (days 2-5) were performed during which the animals were given free access to food and water. The feeding period was followed by a $2 \mathrm{~d}$ fasting period (drinking water allowed; days 6 and 7). The balance studies, including quantitative collection of excreta, sample preparation etc., were carried out as previously described (Wamberg et al. 1996d).

Each morning, between 10.00 and 12.00 hours, feed residues and $24 \mathrm{~h}$ faecal and urinary excretions were carefully collected, weighed and prepared for analysis or stored at $-20^{\circ}$ for subsequent analysis. Portions of urine collected on days -2 and -1 were stored separately for the determination of urea, creatinine and purine derivatives.

The experimental procedures used followed Danish National Legislation and the guidelines approved by the member States of the Council of Europe for the protection of vertebrate animals (Anonymous, 1986).

\section{Analytical methods}

The DM content of samples of the diet was determined by evaporation at $100^{\circ}$ to constant weight. Total $\mathrm{N}$ was determined in food, faeces and urine by the micro-Kjeldahl technique using the Tecator-Kjeltec system 1030 (Tecator AB, Höganäs, Sweden). CP was calculated as $\mathrm{N} \times 6.25$. In plasma and urine the concentrations of urea were measured by the urease (EC 3.5.1.5) method (Hallett \& Cook, 1971), those of creatinine by the alkaline picrate method (Chasson et al. 1961) and plasma albumin by the bromcresol green method (Doumas et al. 1971), using a Technicon ${ }^{\circledR}$ AutoAnalyzer, model RA-1000 (Technicon Instruments Corp., Tarrytown, NY, USA) as previously described (Wamberg et al. 1992). Plasma urate was measured by the uricase (EC 1.7.3.3) method (Town et al. 1985) using the Boehringer Mannheim assay (kit no. MPR 2; Boehringer Mannheim, Mannheim, Germany), and plasma osmolality was determined by means of a vapour pressure osmometer (model 5100B; Wescor, Logan, Utah, USA). The concentrations of the purine derivatives allantoin, uric acid, xanthine and hypoxanthine in urine were measured using the HPLC-technique described by Chen et al. (1993). The chemicals used were analytical 
grade, purchased from E. Merck, Darmstadt, Germany. All analyses were performed in duplicate and the analytical error was calculated to be less than $4 \%$.

\section{Radioisotopes}

The radioisotopes $p$-aminobenzoyl-2- $\left[{ }^{3} \mathrm{H}\right]$ glycine (Amersham, code TRA 197, specific activity $520 \mathrm{mCi}(19.2 \mathrm{GBq}) / \mathrm{mmol}$ ) and inulin $\left[{ }^{14} \mathrm{C}\right]$ carboxylic acid (Amersham, code CFA 399 , specific activity $4.92 \mathrm{mCi}(182 \mathrm{MBq}) / \mathrm{mmol})$ were obtained from Amersham International Plc, Amersham, Bucks. The radioactivities of $\left[{ }^{3} \mathrm{H}\right] \mathrm{PAH}$ and $\left[{ }^{14} \mathrm{C}\right] \mathrm{IN}$ in plasma and urine were determined by liquid-scintillation spectrometry, using the Mark III Liquid Scintillation System (model 6880; Searle Analytical Inc., Elk Grove Village, IL, USA) as previously described (Wamberg et al. 1996a,d).

\section{Data analysis}

Individual samples of urine from each day were analysed separately and the values corrected for inaccuracies inherent in the collecting procedure, using the individual percentage recoveries of $\left[{ }^{3} \mathrm{H}\right] \mathrm{PAH}$ for correction (for details, see Wamberg et al. 1996d). The $24 \mathrm{~h}$ urinary excretion rates of total $\mathrm{N}$, urea, creatinine, uric acid and allantoin were calculated from concentrations in non-acidified urine and in the amount of urine excreted in $24 \mathrm{~h}$ corrected to $100 \%\left[{ }^{3} \mathrm{H}\right] \mathrm{PAH}$ recovery.

In the pre-operative period, $24 \mathrm{~h}$ urinary excretion rates were corrected to $100 \%$ (mean) post-operative $\left[{ }^{3} \mathrm{H}\right] \mathrm{PAH}$ recovery and, when calculating the renal clearances of inulin, individual percentage recoveries of $\left[{ }^{14} \mathrm{C}\right] \mathrm{IN}$ were used.

Mean $24 \mathrm{~h}$ INC and ENCC were calculated according to the conventional definition, $C_{x}=U_{x} \times V / P_{x}$ (Levinsky \& Levy, 1973), where $U_{x}$ is the concentration in urine and $P_{x}$ the plasma concentration of the substance $(X)$, and $V$ is the (corrected) timed excretion of urine. For the present calculations, it was assumed that $1 \mathrm{~g}=1 \mathrm{ml}$ urine (cf. Table 4 and Fig. 1).

\section{Statistics}

As indicated by the data presented in a previous study (Wamberg et al. 1996d) and those given here (Tables 1 and 2, and Fig. 1), the animals recovered to normal behaviour within $24 \mathrm{~h}$ after surgery, and no significant adverse effects were observed in any animal during the balance period. Therefore, in the statistical analysis, comparisons were made between the pre- and post-surgery states in fed animals, and between fed and fasted animals postsurgery by means of Student's $t$ test for paired observations (Armitage \& Berry, 1994). Throughout the study, statistical significance was set at the $5 \%$ level.

\section{RESULTS}

\section{$\operatorname{Expt} A$}

Animal performance and $N$ balance. Normal feed consumption was restored when collections started on day 2 (Table 1), and animal live weights remained stable during the feeding period (Table 2). As a response to feed withdrawal, urine excretion decreased dramatically (Fig. 1(a) and Table 1), and the animals began to lose weight (Table 2). The overall mean percentage recovery of $\left[{ }^{3} \mathrm{H}\right] \mathrm{PAH}$ was 77.9 (SE 2.2) \% during feeding and 70.3 
NITROGEN BALANCE IN ADULT FEMALE MINK

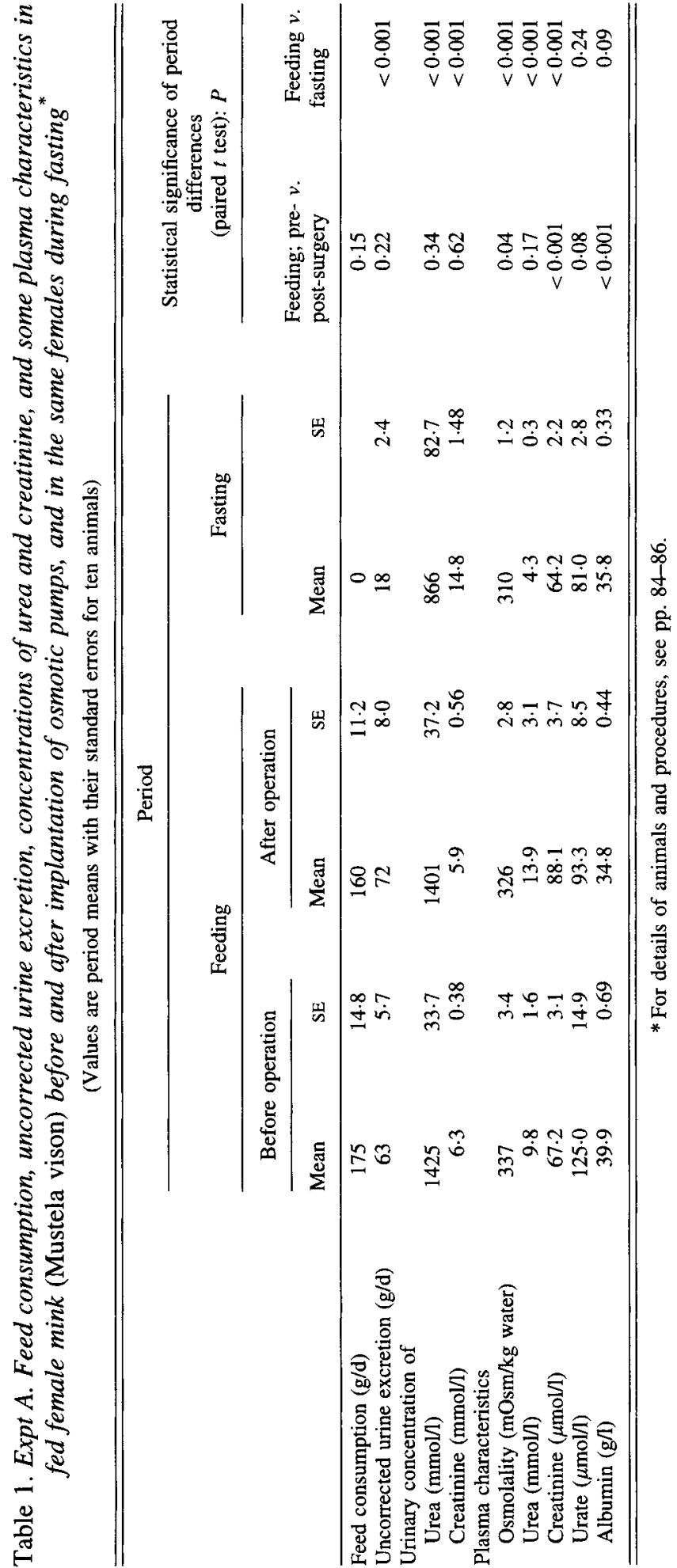


Table 2. Expt A. Animal live weights, recovery of radioactively-labelled $\mathrm{p}$-aminohippuric acid (p-aminobenzoyl-2-[ $\left.{ }^{3} \mathrm{H}\right]$ glycine; $\left.\left[{ }^{3} \mathrm{H}\right] P A H ; \mathrm{n} 10\right)$ and ${ }^{14} \mathrm{C}$-labelled inulin $\left.\left({ }^{14} \mathrm{C}\right] I N ; \mathrm{n} 5\right)$ in fed and fasted female mink (Mustela vison) with implanted osmotic pumps, and data on nitrogen metabolism, corrected to $100 \%\left[{ }^{3} \mathrm{H}\right] \mathrm{PAH}$ recovery $(\mathrm{n} 10)$, and renal clearance data corrected to $100 \%\left[^{3} \mathrm{H}\right] P A H$ recovery $(\mathrm{n} 10)$, or $\left[{ }^{14} \mathrm{C}\right] I N$ recovery $(\mathrm{n} 5)^{*}$

(Values are period means with their standard errors)

\begin{tabular}{|c|c|c|c|c|c|}
\hline & \multicolumn{4}{|c|}{ Period } & \multirow{3}{*}{$\begin{array}{c}\text { Statistical significance o } \\
\text { period effects } \\
\text { (paired } t \text { test): } P\end{array}$} \\
\hline & \multicolumn{2}{|c|}{ Feeding } & \multicolumn{2}{|c|}{ Fasting } & \\
\hline & Mean & SE & Mean & SE & \\
\hline Live wt $(g)$ & 1099 & 37.6 & 1063 & $36 \cdot 6$ & $<0.001$ \\
\hline Wt change $(\mathrm{g} / \mathrm{d})$ & $1 \cdot 3$ & 3.4 & -39.7 & $2 \cdot 8$ & $<0.001$ \\
\hline \multicolumn{6}{|l|}{ Recovery $(\%)$} \\
\hline$\left[{ }^{3} \mathrm{H}\right] \mathrm{PAH}$, total & 77.9 & $2 \cdot 2$ & $70 \cdot 3$ & $2 \cdot 0$ & 0.01 \\
\hline$\left[{ }^{14} \mathrm{C}\right] \mathrm{IN}$, total & 79.1 & $2 \cdot 4$ & 62.7 & $2 \cdot 4$ & $<0.001$ \\
\hline \multicolumn{6}{|l|}{ Corrected $\mathrm{N}$ metabolism } \\
\hline Urine excretion $(\mathrm{g} / \mathrm{d})$ & 93 & $8 \cdot 3$ & 25 & $2 \cdot 7$ & $<0.001$ \\
\hline $\mathrm{N}$ intake $(\mathrm{g} / \mathrm{d})$ & 4.53 & 0.40 & 0 & & \\
\hline$N$ excretion in faeces $(\mathrm{g} / \mathrm{d})$ & $0 \cdot 86$ & $0 \cdot 10$ & 0 & & \\
\hline$N$ excretion in urine $(\mathrm{g} / \mathrm{d})$ & 4.01 & 0.46 & 0.63 & 0.04 & $<0.001$ \\
\hline$N$ excretion, total (g/d) & 4.87 & 0.55 & 0.63 & 0.04 & $<0.001$ \\
\hline $\mathrm{N}$ balance $(\mathrm{g} / \mathrm{d})$ & -0.34 & 0.18 & -0.63 & 0.04 & 0.08 \\
\hline \multicolumn{6}{|l|}{$24 \mathrm{~h}$ urinary excretion } \\
\hline Urea (mmol) & 149.4 & $14 \cdot 3$ & 21.6 & 1.4 & $<0.001$ \\
\hline Creatinine (mmol) & 0.60 & 0.04 & 0.36 & 0.02 & 0.20 \\
\hline \multicolumn{6}{|c|}{ Renal clearance (ml/min per $\mathrm{kg}$ live $\mathrm{wt}^{0.75}$ ) } \\
\hline Creatinine & 4.4 & 0.29 & 3.8 & 0.27 & 0.05 \\
\hline Inulin & $6 \cdot 6$ & 0.52 & 5.5 & 0.46 & 0.20 \\
\hline
\end{tabular}

* For details of animals and procedures, see pp. 84-86.

(SE 2.7) \% during fasting. In most animals $\mathrm{N}$ balances, corrected to $100 \%\left[{ }^{3} \mathrm{H}\right] \mathrm{PAH}$ recovery, were slightly negative during both feeding and fasting (Table 2 ), the difference between feeding and fasting periods, however, was not significant $(P=0.08)$.

Urinary excretion of $N$ metabolites. During fasting, the concentration of urea in urine decreased significantly $(P<0.001)$, whereas urinary creatinine concentration increased significantly (Table 1). The rapid response to fasting of $24 \mathrm{~h}$ urinary excretion of these substances is shown in Fig. 1. Hence, during feeding the mean values (and their relative standard deviation; RSD) for urinary excretion of urea and creatinine were $149.4 \mathrm{mmol} / \mathrm{d}$ (RSD $30.2 \%$ ) and 0.60 (RSD $18.7 \%$ ) $\mathrm{mmol} / \mathrm{d}$, respectively; and during fasting the corresponding $24 \mathrm{~h}$ excretion rates amounted to $21.6 \mathrm{mmol} / \mathrm{d}$ (RSD $17.0 \%$ ) and $0.36 \mathrm{mmol} / \mathrm{d}$ (RSD $15.1 \%$ ) respectively (Table 2 ). These changes reflected a marked and significant decrease in urinary excretion of urea $(P<0.001)$, while the decrease in creatinine excretion was not significant $(P=0 \cdot 20)$.

Plasma constituents. The concentrations of urea and creatinine in blood plasma fluctuated in response to feed intake, with significantly lower concentrations being recorded for fasted animals (Table 1). Plasma urate, on the other hand, remained stable when the animals were fasted (Table 1). Plasma osmolality decreased from the pre- 
(a)

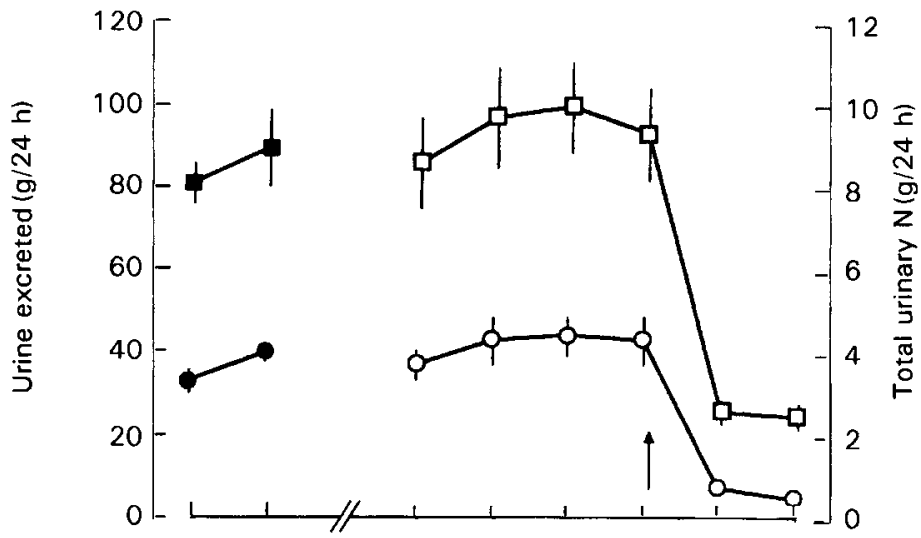

(b)

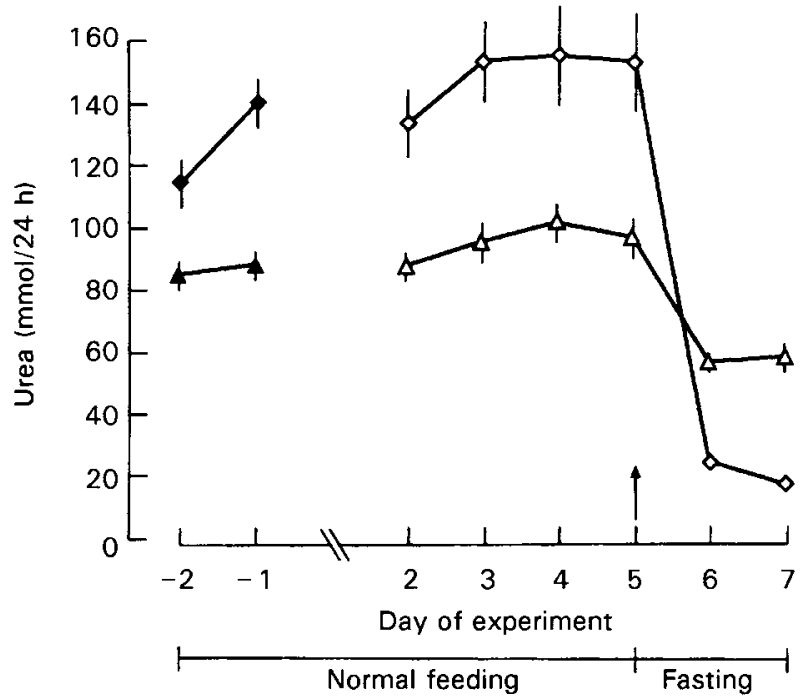

Fig. 1. Expt A. (a) Daily urinary output $(\square)(\mathrm{g} / 24 \mathrm{~h})$ and total nitrogen in urine $(\mathrm{O})(\mathrm{g} / 24 \mathrm{~h})$, corrected to $100 \%$ radioactively-labelled $p$-aminohippuric acid (p-aminobenzoyl-2- $\left[{ }^{3} \mathrm{H}\right]$ glycine; $\left.\left[{ }^{3} \mathrm{H}\right] \mathrm{PAH}\right)$ recovery and (b) urinary excretion rates $(\mathrm{mmol} / 24 \mathrm{~h})$ of urea $(\diamond)$ and creatinine $(\Delta)$, corrected to $100 \%\left[{ }^{3} \mathrm{H}\right] \mathrm{PAH}$ recovery, in ten female mink during normal feeding (pre-experimental days -2 and $-1(\boldsymbol{\square}, \mathbf{O}, \boldsymbol{\bullet}, \mathbf{\Delta}$ ); and experimental days $2-5$ ) and short-term fasting (days 6-7). $\uparrow$, The onset of fasting. Values are means with their standard errors represented by vertical bars. The animals had the osmotic pump implanted on day zero, and no collections were made on day 1 . For details of animals and procedures, see pp. 84-86.

operative period to the feeding period, and then further to the fasting period (Table 1), the lowest plasma osmolality being recorded on the second day of fasting. Plasma albumin was higher in the pre-operative period than during the two experimental periods (Table 1). 
Renal clearance. Mean $24 \mathrm{~h}$ values for ENCC and INC are recorded in Table 2. INC was about $30 \%$ higher than ENCC in the fed as well as in the fasted state. However, during the fasting period, the decrease in INC was not significant $(P=0 \cdot 20)$, whereas ENCC declined to the borderline of significance $(P=0.05)$.

\section{Expt $B$}

Purine derivatives. The 24 excretion rates of purine derivatives in urine as well as urinary excretion of urea and creatinine and some plasma characteristics for animals in Expt $\mathbf{B}$ are presented in Table 3. During feeding, allantoin and total purine excretion were more than double the amounts excreted during fasting. Allantoin accounted for more than $97 \%$ of total purine excretion in fed animals, and in fasted animals it made up more than $98 \%$, which turned out to be significantly $(P=0.05)$ higher than that in fed animals.

\section{DISCUSSION}

\section{Nitrogen balance}

Conventional mink diets are largely based on by-products from the fishing industry and abattoirs and, therefore, are rich in protein and other N-containing constituents; their protein content usually exceeds the animals' requirement. The mink has a very short intestine (Kainer, 1954), and a feed passage time of only 4-6 h (Hansen, 1978; Szymeczko \& Skrede, 1990). Thus, ingested dietary protein is rapidly digested and absorbed, the excess being metabolized to $\mathrm{C}$ fragments used for energy metabolism and to $\mathrm{N}$-containing endproducts which are excreted in the urine. Therefore, in fed animals, the urinary load of $\mathrm{N}$ metabolites is high, with urea accounting for the vast majority of osmotically-active substances (Eriksson et al. 1984). Moreover, large diurnal variations in plasma concentrations and urinary excretion rates of nitrogenous waste products can be expected in response to feed intake, and fasting is likely to induce profound changes in metabolism. Since the dietary intake of protein usually is more than sufficient to fulfil the animals' requirements, adult animals kept on maintenance level are assumed to be in zero $\mathrm{N}$ balance (Owen, 1967), but data in the literature often indicate that positive $\mathrm{N}$ balances have been obtained in adult animals (Charlet-Lery et al. 1980; Jarosz \& Barabasz, 1988; Elnif, 1992). However, as demonstrated by Elnif (1992) the $\mathrm{N}$ balances of adult males approach zero after correction for the estimated retrieval rate of urinary $\mathrm{N}$.

In the present study the animals remained at constant body weight during the feeding period, and $\mathrm{N}$ balances were slightly negative, indicating that the correction to $100 \%$ $\left[{ }^{3} \mathrm{H}\right] \mathrm{PAH}$ recovery resulted in a slight overestimation, presumably due to accumulated analytical errors. In the fasting period rapid weight loss was accompanied by an increased negative $\mathrm{N}$ balance which was of the same order as that for growing mink on a protein-free diet (Berg et al. 1984). Hence, the $\mathrm{N}$ balance data achieved here, and previous data on electrolyte balances (Wamberg et al. 1996d), indicate that the technique used is suitable for accurate determination of nutrient balances in small carnivores, and represents a valuable tool in studies of nutrient requirements. However, owing to its invasive character, it may be emphasized that it is likely to be applied on a limited number of animals only, for example when new experimental procedures or measurements are to be evaluated. 
Table 3. Expt B. Plasma albumin, osmolality and concentrations of urea and creatinine and $24 \mathrm{~h}$ urinary excretion rates of urea, creatinine and purine derivatives in ten fed or fasted female mink (Mustela vison), with urinary excretion rates corrected to $100 \%\left[{ }^{3} \mathrm{HJPAH}\right.$ recovery*

(Values are period means with their standard errors for ten animals)

\begin{tabular}{|c|c|c|c|c|c|}
\hline & \multicolumn{2}{|c|}{ Feeding } & \multicolumn{2}{|c|}{ Fasting } & \multirow{2}{*}{$\begin{array}{c}\text { Statistical significance } \\
\text { of difference } \\
\text { (paired } t \text { test): } P\end{array}$} \\
\hline & Mean & SE & Mean & SE & \\
\hline \multicolumn{6}{|l|}{ Plasma data } \\
\hline Albumin $(g / 1)$ & 36.7 & 0.58 & $35 \cdot 6$ & 0.65 & 0.24 \\
\hline Osmolality (mOsm $/ \mathrm{kg}$ water) & 331 & 1.7 & 316 & $2 \cdot 1$ & $<0.001$ \\
\hline Urea $(\mathrm{mmol} / \mathrm{l})$ & $13 \cdot 0$ & 0.78 & $5 \cdot 0$ & 0.62 & $<0.001$ \\
\hline Creatinine $(\mu \mathrm{mol} / \mathrm{l})$ & $65 \cdot 3$ & 2.05 & $75 \cdot 5$ & $2 \cdot 22$ & 0.003 \\
\hline \multicolumn{6}{|l|}{$24 \mathrm{~h}$ urinary excretion rates } \\
\hline Corrected urine $(\mathrm{g})$ & 75 & 11.7 & 34 & 5.7 & 0.006 \\
\hline Urea (mmol) & 44.4 & $10 \cdot 6$ & 20.7 & $2 \cdot 3$ & 0.04 \\
\hline Creatinine (mmol) & 0.68 & 0.12 & 0.46 & 0.06 & 0.12 \\
\hline Allantoin $(\mu \mathrm{mol})$ & 189.5 & 33.6 & $90 \cdot 4$ & 9.9 & 0.01 \\
\hline Uric acid $(\mu \mathrm{mol})$ & $4 \cdot 0$ & 0.74 & $1 \cdot 2$ & 0.12 & 0.002 \\
\hline Total purines $(\mu \mathrm{mol})$ & 194.5 & $34 \cdot 5$ & 91.8 & $10 \cdot 0$ & $0 \cdot 01$ \\
\hline \multicolumn{6}{|c|}{ Purine derivatives ( $\%$ of total purine) } \\
\hline Allantoin & 97.2 & 0.49 & $98 \cdot 3$ & $0 \cdot 20$ & 0.05 \\
\hline Uric acid & $2 \cdot 3$ & 0.38 & 1.4 & $0 \cdot 16$ & 0.05 \\
\hline Xanthine + hypoxanthine & 0.6 & $0 \cdot 11$ & 0.4 & 0.04 & 0.08 \\
\hline
\end{tabular}

$\left[{ }^{3} \mathrm{H}\right] \mathrm{PAH}, p$-aminobenzoyl-2-[ $\left.{ }^{3} \mathrm{H}\right] \mathrm{glycine}$ ( $p$-aminohippuric acid).

${ }^{*}$ For details of animals and procedures, see pp. 84-86.

\section{Urinary urea and creatinine excretion}

As might be expected because of the high dietary $\mathrm{N}$ intake, urinary excretion of urea and creatinine was substantial during the feeding period, and the dramatic decrease during fasting reflected the withdrawal of the normal dietary load of nitrogenous constituents. This response is in good agreement with recent observations by Wamberg \& Tauson (1996).

As previously discussed, under-collection of urine may be one of the most important sources of error in nutritional studies, and in order to minimize this kind of error, determination of the reproducibility of excretion of suitable endogenous or exogenous substances has been applied. The $24 \mathrm{~h}$ urinary excretion of creatinine has, for instance, been used for several years, and in many species, as an internal standard in the evaluation of quantitative urine collection. Unfortunately, urinary excretion of endogenous creatinine has turned out to be highly variable (rats: Kumar et al. 1959; dogs: Bartges et al. 1994; human subjects: Jackson, 1966; Scott \& Hurley, 1968), depending not only on the rate of glomerular filtration (GFR) but also on the amount of dietary protein intake (mink: Wamberg \& Tauson, 1996; Wamberg et al. 1996b) and on the cooking (Jacobsen et al. 1979; Watson et al. 1981) of dietary meat. The wide range in creatinine excretion (expressed as a percentage of the group mean) found in the present investigation confirms the views of Edwards et al. (1969) and Bingham \& Cummings (1983) that urinary creatinine excretion is unreliable in control of the completeness of urine collection. From our own data it is obvious that recovery rates of continuously delivered $\left[{ }^{3} \mathrm{H}\right] \mathrm{PAH}$ are far 
more reliable. In human studies, oral administration of a suitable urinary marker may be used to solve the problem of incomplete collection of urine (Bingham \& Cummings, 1983).

Finally, the plasma concentrations of urate obtained here were rather high when compared with the levels found in cats (42 (SE 8) $\mu \mathrm{mol} / 1$; Zhang et al. 1994) and in rats (49 (SE 5) $\mu \mathrm{mol} / \mathrm{l}$; Brulé et al. 1988), which may be due to different sources of dietary protein. In our study there were no apparent differences between plasma values obtained in postoperative animals and animals fasted for 1 or $2 \mathrm{~d}$.

\section{Response to fasting}

The response to withdrawal of the feed was rapid, and reflected by a dramatic fall in the renal excretion of water, total urinary $\mathrm{N}$, urea and creatinine. A similar response in urinary water and electrolyte excretion was demonstrated by Wamberg et al. (1995, 1996d). The slight increase in the negative $\mathrm{N}$ balance, as demonstrated for the fasting period, could hardly be explained by extensive breakdown of muscular tissue or liver protein, since the fasting period lasted for only $2 \mathrm{~d}$. This interpretation is supported by the decreased excretion of urea and creatinine in urine.

The diurnal fluctuations in plasma osmolality and plasma concentrations of $\mathrm{N}$ containing metabolites are caused by several factors. The most important of these is the rate of urinary excretion, which depends on the functional status of the kidney. Other influences are dietary composition, episodes of feeding and fasting, gastrointestinal absorption, storage, synthesis and/or metabolic degradation. Thus, the decrease in plasma protein in the post-operative and the fasting periods results from a lower rate of net protein synthesis in the liver. In carnivores, plasma nitrogenous constituents are likely to fluctuate considerably in response to feeding, as demonstrated for dogs (Watson et al. 1981). For mink, Wamberg \& Tauson (1996) demonstrated that both plasma urea and creatinine were markedly influenced by feeding and the time elapsing from the last meal to blood sampling. The present results concur with this concept by demonstrating a profound decrease in plasma urea and creatinine in fasted animals, which was reflected by a significant decrease in plasma osmolality on the second day of fasting.

\section{Renal clearances}

As a response to dietary protein loading a temporary increase in renal blood flow and GFR can be expected (Watson et al. 1981). Moreover, the rate of formation of metabolites will increase, and together with the change in GFR, this will lead to increased rates of urinary solute and water excretion. In the present study, this was reflected in relatively large variations in the plasma concentrations of urea and creatinine during feeding. Since ENCC and INC were based on a single blood sample obtained for each $24 \mathrm{~h}$ period, the calculated mean values for ENCC and INC presented here should only be taken as rough estimates of the mean $24 \mathrm{~h}$ value for GFR. Despite this fact, the mean $24 \mathrm{~h}$ clearance values obtained in the present study are in accordance with the clearance data reported in the literature for endogenous creatinine in fed (awake) animals as well as for exogenous creatinine, inulin or radioactively-labelled substances in fasted, anaesthetized cats, ferrets and mink (Table 4). Comparable values for $24 \mathrm{~h}$ ENCC are found in awake dogs (mean 3.7 (SE 0.13) $\mathrm{ml} / \mathrm{min}$ per $\mathrm{kg}$; Bovée \& Joyce, 1979) and in dogs fed on diets containing varied amounts of protein (range $2.2-3.3 \mathrm{ml} / \mathrm{min}$ per $\mathrm{kg}$; Bartges et al. 1996). The unexpectedly small decrease in the 
Table 4. Literature data on estimated glomerular filtration rates (GFR) in cats, ferrets (Mustela putorius furo) and mink (Mustela vison)

\begin{tabular}{|c|c|c|c|c|c|c|}
\hline \multirow[b]{2}{*}{ Author(s) } & \multirow{2}{*}{$\begin{array}{l}\text { Animal } \\
\text { species }\end{array}$} & \multirow[b]{2}{*}{$n$} & \multicolumn{2}{|c|}{$\begin{array}{l}\text { Estimated GFR } \\
(\mathrm{ml} / \mathrm{min} \text { per } \mathrm{kg})\end{array}$} & \multirow{2}{*}{$\begin{array}{l}\text { Clearance } \\
\text { technique }\end{array}$} & \multirow{2}{*}{$\begin{array}{l}\text { Anaesthesia and } \\
\text { comments }\end{array}$} \\
\hline & & & Mean & $\mathbf{S E}$ & & \\
\hline \multirow[t]{2}{*}{ Ross \& Finco (1981) } & Cats & 11 & 2.94 & $0 \cdot 10$ & EXCC & Pentobarbital \\
\hline & Cats & 8 & 3.51 & 0.21 & INC & Pentobarbital \\
\hline Russo et al. (1986) & Cats & 12 & $2 \cdot 31$ & $0 \cdot 14$ & ENCC & Awake, $24 \mathrm{~h}$ urine collection \\
\hline \multirow[t]{3}{*}{ Rogers et al. (1991) } & Cats & 6 & 2.56 & 0.25 & EXCC & Halothane \\
\hline & & & 3.07 & $0 \cdot 31$ & INC & Halothane \\
\hline & & & $2 \cdot 60$ & 0.29 & ${ }^{99 m}$ TcD'TPA & Halothane \\
\hline Adams et al. (1991) & Cats & 6 & $2 \cdot 15$ & 0.12 & INC & Halothane \\
\hline Kim et al. (1992) & Cats & 29 & $2 \cdot 96$ & $0 \cdot 15$ & INC & Thiopentotal \\
\hline \multirow[t]{3}{*}{ Esteves et al. (1994) } & Ferrets & 26 & 2.55 & 0.21 & ENCC & Awake, $24 \mathrm{~h}$ urine collection \\
\hline & Ferrets & 12 & $3 \cdot 32$ & 0.46 & $\mathrm{EXCC}$ & Isoflurane $(50 \mathrm{ml} / \mathrm{h})$ \\
\hline & Ferrets & 12 & 3.02 & $0-27$ & INC & Isoflurane $(50 \mathrm{ml} / \mathrm{l})$ \\
\hline $\begin{array}{l}\text { Müller-Peddinghaus } \\
\text { et al. (1979) }\end{array}$ & Mink, female & 3 & 6.5 & $1 \cdot 0$ & ${ }^{51}$ CrEDTA & Xylazin + ketamin \\
\hline \multirow[t]{4}{*}{ Present study } & Mink, female & 10 & $4 \cdot 37$ & 0.25 & ENCC & Awake, fed animals \\
\hline & & & 3.80 & $0-35$ & ENCC & Awake, fasted animals \\
\hline & Mink, female & 5 & 6.64 & $0-43$ & INC & Awake, fed animals \\
\hline & & & $5 \cdot 51$ & 0.61 & INC & Awake, fasted animals \\
\hline
\end{tabular}

EXCC, Exogenous creatinine clearance; INC, inulin clearance; ENCC, endogenous creatinine clearance; DTPA, diethylene-triaminepenta-acetic acid.

mean $24 \mathrm{~h} \mathrm{INC}$ in response to fasting observed in our study can be explained mainly by the calculations being based on a single blood sample for each $24 \mathrm{~h}$ period.

\section{Purine derivatives}

Data on excretion of purine derivatives have, to our knowledge, not previously been reported for mink. The present results indicate that allantoin is the major route of excretion, that uric acid makes up only a minor part, and that fasting resulted in a marked reduction in urinary excretion of total purine derivatives to less than half the level observed during feeding, and that the relative importance of allantoin increased.

\section{Conclusions}

The results of the present study show that the use of implanted osmotic pumps for continuous release of a urinary marker permits reproducible and accurate determination of total urine excretion, and calculation of correct $\mathrm{N}$ balances in experimental animals. Moreover, they demonstrate profound differences in urinary excretion of $\mathrm{N}$ metabolites between fed and fasted animals, and that the response to fasting is rapid. Allantoin was shown to be the major route for excretion of purine derivatives. INC and ENCC were of the same order of magnitude as those for other carnivores. In both cases, however, the decrease in response to short-term fasting was less than expected.

Finally, the use of implanted osmotic pumps has proved a valuable tool for the accurate determination of nutrient balances in small carnivores kept under well-defined experimental conditions. In a broader perspective, the results of the present investigation 
emphasize the importance of adequate control of quantitative urine collection in nutritional, pharmacological or toxicological studies in all mammalian species, including human subjects.

This study was supported by The Danish Agricultural and Veterinary Research Council (grants no. 13-4905/1 and 13-4906/1) and by The Danish Fur Breeder's Association. The authors wish to thank Inge Andersen, Lise Larsen, Annette Linde, Boye Pedersen and Merethe Stubgaard for skilled technical assistance throughout the study. We are also grateful to Dr X. B. Chen, The Rowett Research Institute, Bucksburn, Aberdeen, Scotland for analysing the purine derivatives in mink urine.

\section{REFERENCES}

Adams, L. G., Polzin, D. J., Osborne, C. A. \& O'Brien, T. D. (1991). Comparison of fractional excretion and $24-$ hour urinary excretion of sodium and potassium in clinically normal cats and cats with induced chronic renal failure. American Journal of Veterinary Research 52, 718-722.

Anonymous (1986). European Convention for the Protection of Vertebrate Animals Used for Experimental and other Scientific Purposes. European Treaty Series no. 123. Strasbourg: Council of Europe.

Armitage, P. \& Berry, G. (1994). Statistical Methods in Medical Research, 3rd ed., pp. 94-114. Oxford: Blackwell Scientific Publications.

Baker, D. H. (1986). Problems and pitfalls in animal experiments designed to establish dietary requirements for essential nutrients. Journal of Nutrition 116, 2339-2349.

Bartges, J. W., Osborne, C. A., Felice, L. J., Unger, L. K., Bird, K. A., Koehler, L. A. \& Chen, M. (1994). Reliability of single urine and serum samples for estimation of 24-hour urinary uric acid excretion in six healthy Beagles. American Journal of Veterinary Research 55, 472-476.

Bartges, J. W., Osborne, C. A., Lawrence, J. F., Unger, L. K., Koehler, L. A., Bird, K. A. \& Chen, M. (1996). Influence of four diets on uric acid metabolism and endogenous acid production in healthy Beagles. American Journal of Veterinary Research 57, 324-328.

Berg, H., Valtonen, M., Tång, L. \& Eriksson, L. (1984). Protein digestibility and water and nitrogen balance studies with mink at different protein levels. In Proceedings 3rd International Scientific Congress in Fur Animal Production, France, communication no. 9, pp. 1-7 [Institut National de la Recherche Agronomique et Institut Technique de l'Aviculture, editors]. Paris: Institut Technique de l'Aviculture.

Bingham, S. \& Cummings, J. H. (1983). The use of 4-aminobenzoic acid as a marker to validate the completeness of 24-h urine collections in man. Clinical Science 64, 629-635.

Bovée, K. C. \& Joyce, T. (1979). Clinical evaluation of glomerular function: 24-hour creatinine clearance in dogs. Journal of American Veterinary Medical Association 174, 488-491.

Brulé, D., Sarwar, G., Savoie, L., Campbell, J. \& van Zeggelaar, M. (1988). Differences in uricogenic effects of dietary purine bases, nucleosides and nucleotides in rats. Journal of Nutrition 118, 780-786.

Børsting, C. F. \& Clausen, T. N. (1996). Requirements of essential amino acids for mink. In Protein Metabolism and Nutrition. Proceedings of the 7 th International Symposium on Protein Metabolism and Nutrition. European Association of Animal Production Publication no. 81, p. 169 [A. F. Nunes, A. V. Portugal, J. P. Costa and J. R. Ribeiro, editors]. Vale de Santarem: Estacio Zootecnica Nacional.

Charlet-Lery, G., Fislewicz, M. \& Morel, M.-T. (1980). Energy and nitrogen balances in male mink during the adult life. In Proceedings 2nd International Scientific Congress in Fur Animal Production, paper no. 80-34, pp. 1-5 [G. Jørgensen, editor]. Vedbaek, Denmark: Scandinavian Association of Agricultural Scientists.

Chasson, A. L., Grady, H. J. \& Stanley, M. A. (1961). Determination of creatinine by means of automatic chemical analysis. American Journal of Clinical Pathology 35, 83-89.

Chen, X. B., Kyle, D. J. \& Ørskov, E. R. (1993). Measurement of allantoin in urine and plasma by high performance liquid chromatography with pre-column derivatization. Journal of Chromatography 617, 241247.

Doumas, B. T., Watson, W. A. \& Biggs, H. G. (1971). Albumin standards and the measurement of serum albumin with bromcresol green. Clinica Chimica Acta 31, 87-96.

Edwards, O. M., Bayliss, R. I. S. \& Millen, S. (1969). Urinary creatinine excretion as an index of the completeness of 24-hour urine collections. Lancet ii, 1165-1166.

Eggum, B. O. (1989). Biochemical and methodological principles. In Protein Metabolism in Farm Animals. Evaluation, Digestion, Absorption and Metabolism, pp. 1-53 [H. D. Bock, B. O. Eggum, A. G. Low, O. Simon and T. Zebrowska, editors]. Berlin: Oxford Science Publications and Deutscher Landwirtschaftsverlag.

Elnif, J. (1992). Accuracy of nitrogen balance measurements of adult mink. Norwegian Journal of Agricultural Science 9, Suppl., 254-260. 
Eriksson, L., Valtonen, M. \& Mäkelä, J. (1984). Water and electrolyte balance in male mink (Mustela vison) on varying dietary $\mathrm{NaCl}$ intake. Acta Physiologica Scandinavica 537, Suppl., 59-64.

Esteves, M. I., Marini, R. P., Ryden, E. B., Murphy, J. C. \& Fox, J. G. (1994). Estimation of glomerular filtration rate and evaluation of renal function in ferrets (Mustela putorius furo). American Journal of Veterinary Research 55, 166-172.

Fomon, S. J. \& Owen, G. M. (1962). Comment on metabolic balance studies as a method of estimating body composition of infants. Pediatrics 29, 495-498.

Fox, L. A. D., Jansen, G. R. \& Knox, K. L. (1973). Effect of variations in protein quality on growth PER, NPR and NPU in growing kittens. Nutrition Reports International 7, 621-631.

Glem-Hansen, N. (1979). Protein requirement for mink in the lactation period. Acta Agricultura Scandinavica 29, 129-137.

Glem-Hansen, N. (1980). The protein requirements of mink during the growth period. I. Effect of protein intake on nitrogen balance. Acta Agriculture Scandinavica 30, 336-344.

Hallett, C. J. \& Cook, J. G. H. (1971). Reduced nicotinamide adenine dinucleotide-coupled reaction for emergency blood urea estimation. Clinica Chimica Acta 35, 33-37.

Hansen, N. E. (1978). The influence of sulfuric acid preserved herring on the passage time through the gastrointestinal tract in mink. Zeitschrift für Tierphysiologie, Tierernährung und Futtermittelkunde 32, $233-239$.

Jackson, S. (1966). Creatinine in urine as an index of urinary excretion rate. Health Physics 12, 843-850.

Jacobsen, F. K., Christensen, C. K., Mogensen, C. E., Andreasen, F. \& Heilskov, N. S. C. (1979). Pronounced increase in serum creatinine concentration after eating cooked meat. British Medical Journal 1, 1049-1050.

Jarosz, S. \& Barabasz, B. (1988). Effect of various levels of dietary protein and energy on nitrogen retention in pregnant fitch. In Biology, Pathology and Genetics of Fur Bearing Animals. Proceedings of the 4th International Scientific Congress in Fur Animal Production, pp. 377-381 [B. D. Murphy and D. B. Hunter, editors]. Toronto: International Fur Animal Science Association.

Just, A., Fernández, J. A. \& Jørgensen, H. (1982). Nitrogen balance studies and nitrogen retention. In Digestive Physiology in the Pig. Les Colloques de l'INRA no. 2, pp. 111-122 [J. P. Laplace, T. Corring and A. Rerat, editors]. Paris: Institut National de la Recherche Agronomique.

Kainer, R. A. (1954). The gross anatomy of the digestive system of the mink. II. American Journal of Veterinary Research 15, 91-97.

Kim, Y. K., Jung, D. K., Jung, J. S. \& Lee, S. H. (1992). Urate excretion by the cat kidney. Comparative Biochemistry and Physiology 102A, 735-739.

Kumar, I., Land, D. G. \& Boyne, A. W. (1959). The determination of body composition of living animals. The daily endogenous creatinine excretion as a measure of body composition in rats. British Joumal of Nutrition 13, 320-329.

Levinsky, N. G. \& Levy, M. (1973). Clearance techniques. In Handbook of Physiology, Sect. 8, pp. $103-117$ [J. Orloff and R. W. Berliner, editors]. Washington, DC: The American Physiological Society.

Miller, S. A. \& Allison, J. B. (1958). The dietary nitrogen requirements of the cat. Journal of Nutrition 64, 493500.

Müller-Peddinghaus, R., Hackbarth, H., Alt, J. \& Küpper, W. (1979). Untersuchungen zur physiologischen Proteinurie des Nerzes. Vergleich von Proteinurie und Glomerulärer Filtrationsrate mit histologischen Befünden (Studies on physiological proteinuria in the mink. Comparison of proteinuria and glomerular filtration rate with histological findings). Zentralblatt für Veterinärmedizin 26, 130-145.

Neergaard, L. (1981). Comparison of balance technique with slaughter technique in assessment of nitrogen retention in rats. Zeitschrift für Tierphysiologie, Tieremährung und Futtermittelkunde 46, 214-220.

Oddoye, E. A. \& Margen, S. (1979). Nitrogen balance studies in humans: long-term effect of high nitrogen intake on nitrogen accretion. Journal of Nutrition 109, 363-377.

Owen, E. C. (1967). Nitrogen balances. Proceedings of the Nutrition Society 26, 116-124.

Piechota, T. R., Rogers, Q. R. \& Morris, J. G. (1995). Nitrogen requirement of cats during gestation and lactation. Nutrition Research 15, 1535-1546.

Rogers, K. S., Komkov, A., Brown, S. A., Lees, G. E., Hightower, D. \& Russo, A. E. (1991). Comparison of four methods of estimating glomerular filtration rate in cats. American Journal of Veterinary Research 52, 961-964.

Ross, L. A. \& Finco, D. R. (1981). Relationship of selected clinical renal function tests to glomerular filtration rate and renal blood flow in cats. American Journal of Veterinary Research 42, 1704-1710.

Russo, E. A., Lees, G. E. \& Hightower, D. (1986). Evaluation of renal function in cats, using quantitative urinalysis. American Journal of Veterinary Research 47, 1308-1312.

Scott, P. J. \& Hurley, P. J. (1968). Demonstration of individual variation in constancy of 24-hour urinary creatinine excretion. Clinica Chimica Acta 21, 411-414.

Skrede, A. (1978). Utilization of fish and animal byproducts in mink nutrition. I. Effect of source and level of protein on nitrogen balance, postweaning growth and characteristics of winter fur quality. Acta Agriculturce Scandinavica 28, 105-129.

Szymeczko, R. \& Skrede, A. (1990). Protein digestion in mink. Acta Agricultura Scandinavica 40, 189-200.

Town, H.-H., Gehm, S., Hammer, B. \& Ziegenhorn, J. (1985). A sensitive colorimetric method for the enzymatic determination of uric acid. Journal of Clinical Chemistry and Clinical Biochemistry 23, 591. 
Työppönen, J., Berg, H. \& Valtonen, M. (1987). Effects of dietary supplement of methionine and lysine on blood parameters and fur quality in mink fed with low-protein diets. Acta Agricultura Scandinavica 37, 487-494.

Työppönen, J., Valtonen, M. \& Berg, H. (1986). Low-protein feeding in mink: effects on plasma free amino acids, clinical blood parameters, and fur quality. Acta Agricultura Scandinavica 36, 421-428.

van Es, A. J. H. (1975). Interpretation of N-balance experiments. Proceedings 9th International Congress of Nutrition, Mexico, vol 3, pp. 107-113 [A. Chávez, H. Burges and S. Basta, editors]. Basel: S. Karger.

Wamberg, S., Clausen, T. N., Olesen, C. R. \& Hansen, O. (1992). Nursing sickness in lactating mink (Mustela vison) II. Pathophysiology and changes in body fluid composition. Canadian Journal of Veterinary Research 56, 95-101.

Wamberg, S., Elnif, J. \& Tauson, A.-H. (1995). Rates of urinary water, electrolyte and nitrogen excretion in fed and fasted female mink (Mustela vison). Acta Physiologica Scandinavica 155, 28A Abstr.

Wamberg, S., Elnif, J. \& Tauson, A. H. (1996a). Assessment of the accuracy of quantitative urine collection in mink (Mustela vison) using osmotic pumps for continuous release of $p$-amino-hippuric acid and inulin. Laboratory Animals 30, 267-272.

Wamberg, S., Elnif, J. \& Tauson, A.-H. (1996b). Improved accuracy of quantitative urine collection in mink (Mustela vison). In Protein Metabolism and Nutrition. Proceedings of the 7th International Symposium on Protein Metabolism and Nutrition. European Association of Animal Production Publication no. 81, p. 429 [A. F. Nunes, A. V. Portugal, J. P. Costa and J. R. Ribeiro, editors]. Vale de Santarem: Estacio Zootecnica Nacional.

Wamberg, S., Svendsen, P. \& Johansen, B. (1996c). Acid-base status and cardiovascular function in mink (Mustela vison) anaesthetized with ketamine/midazolam. Laboratory Animals 30, 55-66.

Wamberg, S. \& Tauson, A.-H. (1996). Influence of dietary protein intake on plasma urea and creatinine concentrations in female mink (Mustela vison) (Abstract). Proceedings of the Society for Animal Clinical Biochemistry, p. 81 [T. D. G. Watson, editor]. Glasgow: University of Glasgow.

Wamberg, S., Tauson, A.-H. \& Elnif, J. (1996d). Effects of feeding and short-term fasting on water and electrolyte turnover in female mink (Mustela vison). British Journal of Nutrition 76, 711-725.

Watson, A. D. J., Church, D. B. \& Fairburn, A. J. (1981). Postprandial changes in plasma urea and creatinine in dogs. American Joumal of Veterinary Research 42, 1878-1880.

Zhang, Y. L., Li, T. \& Lautt, W. W. (1994). Adenosine metabolism in vivo. Proceedings of the Western Pharmacology Society 37, 15-16. 